International Journal of Instruction e-ISSN: 1308-1470 • www.e-iji.net

Article submission code: 20191007232413

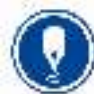

January $2021 \bullet$ Vol.14, No.1

p-ISSN: 1694-609X

pp. 537-554

Received: 07/10/2019

Revision: 09/07/2020
Accepted: 01/08/2020

OnlineFirst: 31/10/2020

\title{
Quality Management of Mathematics Manipulative Products to Support Students' Higher Order Thinking Skills
}

\section{Isti Hidayah}

Dr., Universitas Negeri Semarang, Indonesia, isti.hidayah@mail.unnes.ac.id

Isnarto

Universitas Negeri Semarang, Indonesia, isnarto.math@mail.unnes.ac.id

Masrukan

Universitas Negeri Semarang, Indonesia, masrukan.mat@mail.unnes.ac.id

\section{Mohammad Asikin}

Universitas Negeri Semarang, Indonesia, asikin.mat@mail.unnes.ac.id

\section{Margunani}

Universitas Negeri Semarang, Indonesia, margunani@mail.unnes.ac.id

The Indonesian 2013 curriculum requires the learning process to provide opportunities for the students to develop their higher order thinking skills. Many studies believe that the use of manipulatives are effective to foster it. However, we found that the manipulatives only available for the classroom use, while the students need to also exercise using individual manipulatives outside the class. This study aims to explain the production quality management of individual manipulatives such that they can be highly accessible for students. This study was a development research consisted of eight steps - manipulatives identification, product design, preparation, production, simulation and expert validation, limited testing and revisions, packaging, and marketing. In the simulation and validation stage, 55 teachers and 60 principals were involved as the participants, while during the testing, we involved 92 junior high school students and 58 children. The results suggested that we have successfully produced 14 types of individual manipulatives ready to sell. Moreover, the participants also gave positive responses - at an average of $94 \%$ - that the individual manipulatives could support the development of higher-order thinking skills.

Keywords: quality management, higher-order thinking skills, individual manipulatives, mathematics learning, thinking skills

\section{INTRODUCTION}

The Indonesian 2013 curriculum suggests that the implementation of learning at the elementary and junior high school has to be relevant to the students' characteristics.

Citation: Hidayah, I., Isnarto., Masrukan., Asikin, M., \& Margunani. (2021). Quality Management of Mathematics Manipulative Products to Support Students' Higher Order Thinking Skills. International Journal of Instruction, 14(1), 537-554. https://doi.org/10.29333/iji.2021.14132a 
Based on the graduates' competence standard, the learning objectives should develop the students' attitude, knowledge, and skills. The attitude is fostered through the activities of receiving, implementing, appreciating, living and practicing. The knowledge is constructed through the activities of remembering, understanding, implementing, analyzing, evaluating, and creating. The skills are developed through the activities of observing, asking, trying, reasoning, presenting, and creating (MOEC, 2016).

Through physical and mental activities, students need to be facilitated to exercise the higher order thinking skills (HOTS). According to the Bloom's taxonomy, the higher order thinking skills consist of the upper three stages - analysis, evaluation, and creation (Anderson \& Krathwohl, 2001; Liu, 2010). The stages of analysis and evaluation require critical thinking, while the stage of creation requires creative thinking (Apino \& Retnawati, 2016). These critical and creative thinking skills are also parts of the mathematics learning objectives. To foster the critical and creative thinking, as well as the higher order thinking in general, many argue that teachers need to utilize manipulatives (Furner \& Worrel, 2017; Kontaş, 2016; Laski et al., 2015).

Manipulatives are physical objects designed to represent concretely the abstract objects of mathematics (Furner \& Worrel, 2017) and the students could manipulate it to learn a mathematics concept (Istiandaru et al., 2017). In mathematics learning, the existence of manipulative is needed, especially for the students in basic education to visualize the abstract mathematical objects (Hidayah et. al., 2018). Even more, it is not only students, but also teachers sometimes need a visual media to solve mathematical tasks (Toscano et. al., 2019). The existence of the manipulatives does help the students' abstraction and makes the students achieve higher cognitive development (Kontaş, 2016).

Mathematics manipulatives are better utilized along with a series of activities designed to reinvent mathematics concepts (Hidayah et al., 2018). By using the manipulatives, students could observe, try, and reason various mathematics concepts using concrete material. These activities, according to MOEC (2016), are called scientific activities that can facilitate the students to develop their higher order thinking skills. A teacher could facilitate junior high school students to develop their higher-order thinking skills by providing non-routine problems and making them engaged actively in the learning process (student-centered) (Agustyaningrum, 2015). Furhermore, the students of elementary and junior high school's mental development are at the transition from the concrete stages to abstract. Therefore, mathematics learning requires manipulatives to help them thinking and also makes the mathematics learning fun (Hidayah et. al., 2016). The teacher needs to facilitate the students to make the thinking process run well. Conversely, the teachers require learning media, materials, and guidance of instructions to help the students learn and achieve the learning goals (Gall et. al., 2003; Newby et al., 2000).

Learning design equipped by worksheet and concrete material is effective for developing HOTS (Apino \& Retnawati, 2016; Musfiqi \& Jailani, 2014; Limbach \& Waugh, 2010). HOTS promotion can be done by integrating ICT and objects into learning (Harvey, 2005), as well as implementing problem-based learning (Saido et al., 2017). The manipulatives utilization is done to overcome the limitations of the students' 
mental development in the stage of operational concrete (Hidayah et al., 2016; Hidayah \& Sugiarto, 2015; Khoerunnisa et. al., 2016). The use of manipulatives will facilitate the students to be able to explore. Though there is a negative correlation between the percentage of time spent explaining concepts and the cognitive levels of children (Marshall \& Horton, 2011), there is also a high positive correlation between the percentage of time spent exploring the concept and the cognitive level of students when they use manipulatives (Abdullah et al., 2017; Osman et al., 2012).

Though many studies have shown the advantages of manipulatives to foster the students' higher order thinking skills, the use of manipulatives is still limited to the use of classical and group learning. The students, therefore, could not repeat to try the manipulatives by themselves after class. The nature of the manipulatives is that they can be manipulated by the students to gain specific concepts. The presence of manipulatives does not guarantee the effectiveness of learning. The existence of manipulatives is important, but how to use them properly in a designed learning activity is also important. To overcome this problem, it requires the existence of individual manipulatives, which can be the students' belonging, can be used at anytime and anywhere according to the students' needs. Unfortunately, individual manipulatives are not yet available in the market.

This research, therefore, aims to explain the production quality management of individual manipulatives such that they can be highly accessible to support the students' higher-order thinking skills.

\section{Research Question}

The research questions addressed in this study are (1) how did the development and production management of individual manipulatives run? and (2) what do the teachers' and the students' responses towards the individual manipulatives during the limited testing?

\section{Theoretical Background}

\section{Higher-order thinking skill}

Bloom's taxonomy has been revised (Anderson \& Krathwohl, 2001; Krathwohl, 2002). The taxonomy becomes (1) remember, (2) understand, (3) apply, (4) analyze, (5) evaluate, and (6) create, as presented in Figure 1. The indicators of each stage are (1) Remembering: recognizing and recalling; (2) Understanding: interpreting, exemplifying, classifying, summarizing, inferring, comparing, and explaining; (3) Applying: executing and implementing; (4) Analyzing: differentiating, organizing, and attributing; (5) Evaluating: checking and critiquing; and (6) Creating: generating, planning, and producing (Amstrong, 2016). The students who could do the final stage (creating) means that they have been skilled in the previous stages. The curriculum demands that learning develop higher-order thinking skills according to the revised Bloom's Taxonomy. The taxonomy has also accommodated the factual, conceptual, procedural, and metacognitive knowledge. 


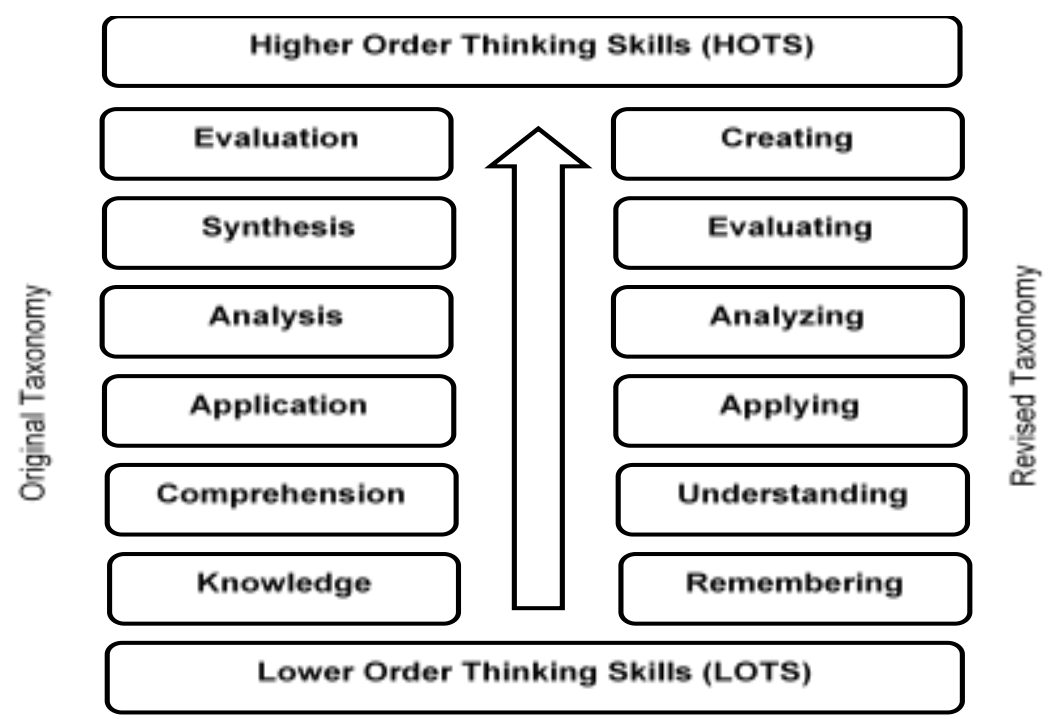

Figure 1

The revised Bloom taxonomy

According to Bloom, learning can start from the lower order thinking skills to the higher order thinking skills. Bloom's levels regarded as the HOTS are analysis, evaluation, and creation (Liu, 2010).

\section{Manipulatives and Question Series}

Manipulatives are objects to help students grasping mathematical concepts by doing kinds of manipulation (Hidayah et al., 2018). Many argue that manipulatives could help students understanding mathematical objects better, but some also said that the presence of manipulatives could not guarantee that (Furner \& Worrell, 2017). However, it is commonly believed that students in the cognitive level of operational concrete need it very much in mathematics learning (Ojose, 2008).

The use of manipulatives will impact better when it is integrated with a series of good questions to drive the students' discovery through activities (Hidayah et al., 2018). Questioning has been proven an effective means of scaffolding the high-level thinking processes of students (Lee \& Chen, 2015). The good questions, along with manipulatives, help the students to foster the higher order thinking skills.

\section{Quality Management of Manipulatives}

Quality management in this research includes the design stage, production stage, evaluation stage, and follow up stage. The stages ensure the quality of the production process and the products. The quality management aims to fulfill the stakeholders' needs and to improve the production by reducing the failure and remake (Juran \& Godfrey, 1998; Kull \& Wacker, 2010; Schniederjans \& Schniederjans, 2015). The practice of 
quality management refers to the management strategy and plan which are important to help a company to improve the quality, to reduce the cost, and to increase the productivity (Dahlgaard-Park, 2011; van der Wiele et al., 2011; Zhang et al., 2016).

Moreover, some argue that there is a positive correlation between quality management and innovation (creativity). Creativity is considered as a source of innovation, which is important in the success of product development (Huang et al., 2017). The application of quality management principles positively and significantly impacts company performance quality (Barros et. al., 2014). The study shows that quality management could trigger the company innovation to reach sustainable competitive excellence. Quality management also has the potential to strengthen the product, process, and innovation (Schniederjans \& Schniederjans, 2015).

Quality management has two aspects, namely, social and technical quality management. Social quality management, for instance, is reflected when a company needs to train its workers and enable inter-function cooperation to produce a high-quality product. Meanwhile, control on the process and product by renewing production tools belongs to technical quality management (Schniederjans \& Schniederjans, 2015). In this research, quality management was applied by revising the tools such that we do produce not only innovative products but also innovative production tools.

\section{METHOD}

\section{Research Design}

Besides mathematics education, this study was carried out in collaboration with experts in accounting, mechanical engineering, and small industry. This study was the first-year research from a multi-year research design with a large design referring to the $R \& D$ design (Gall et al., 2003). The network strengthening in this study took the role as the quality assurance of sustainable production. The target of this study was the product of individual manipulatives. The criteria for individual manipulatives include smaller size (compared to the classical manipulatives), practically carried, and affordable prices for students. The research design is illustrated in Figure 2.

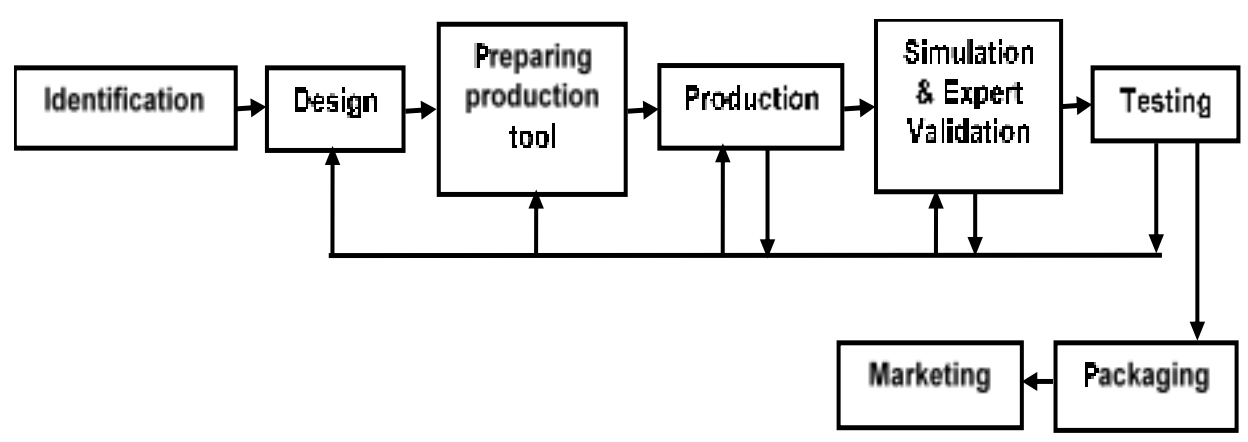

Figure 2

Research design 


\section{Stage I (Manipulative Identification)}

We conducted an identification by studying the classical manipulatives from the findings of our previous projects that have been tested for their effectiveness (Hidayah \& Sugiarto, 2015; Hidayah et al., 2016; Hidayah et al., 2018). We also studied the students' activities (physical and thinking) to support HOTS. From this stage, we got the the kinds of individual manipulatives to be developed hand in hand with the physical and mental activities to foster HOTS.

\section{Stage II (Designing Individual Manipulatives)}

The manipulative design is important to determine the manipulative production supporting tools. The design includes raw materials and sizes. This study is limited to the development of individual manipulatives for planar figure made of $2 \mathrm{~mm}, 4 \mathrm{~mm}$, or $5 \mathrm{~mm}$ evafoam material. The size of the manipulative was determined by considering the purpose of its use.

\section{Stage III (Production Tool Preparation)}

The preparation of tools to produce manipulatives was done considering efficiency and effectiveness because these two factors can affect the market. The effectiveness and the efficiency of the production tools will affect the price for customers, namely the students and the teachers.

\section{Stage IV (Production)}

In the production process, the effectiveness and efficiency of the product were measured. The effectiveness was measured by the relevancy of the design and the purpose of using manipulatives, while the efficiency was measured by the time needed to produce a certain number of products. Furthermore, the human factor (the conditions of the employees in the production) and the quality of the products were also considered. As part of the product quality assurance, the case of the unsuitable product regarding the efficiency and effectiveness were used to improve the design and production tools.

\section{Stage V (Simulation and Expert Validation)}

The product was then validated by experts, including the academics, practitioners (teachers), and policymakers (school principals). In this stage, we also asked if the design of individual manipulatives, along with the students' activities to use them, has been theoretically match with the effort to foster the HOTS. For example, we asked if the products enable the students to explore, to organize, to check, and to create various forms based on the leaning objectives. The validation results were used to improve the products both in the design, preparation, and production processes.

\section{Stage VI (Limited Testing)}

The limited testing was conducted to determine the students' response to the utilization of manipulatives products. We also observed the students' activities using the products in terms of fostering the HOTS. From the results of the students' response, we improve 
the design, preparation of tools, and production processes to get the product relevant to the students' needs.

Stage VII (Packaging)

This stage was also highly considered as it could determine the consumer interest.

\section{Stage VIII (Marketing)}

The purpose of this study is not only facilitating the students to learn not only at school but also at home. Thus, the manipulatives products need to be available in the market.

\section{Participant}

The implementation of this study involves several participants, namely academics, practitioners (teachers), policymakers (principals), and students. The academics, policymakers, and practitioners were involved in conducting expert validation of the manipulative products. While the limited testing was conducted towards the students of SMP N 22 Semarang - a public junior high school in Semarang Indonesia-which involved 92 students. The selection of the students of SMP N 22 Semarang as the research participants was because we have good access to test the manipulatives. Since the products were aimed not only for classical learning at school, but anywhere, anytime, and anyone, the limited testing was also conducted in Mathematics Village. It was a child learning group outside school hours involving 58 children. The mathematics village was chosen since the learning group provides wider chance for us to test the manipulatives. Moreover, there were also 55 teachers and 60 principals involved in the expert validation while responding to activities with the individual manipulatives to support HOTS. These respondents were selected because they join the council of mathematics teachers and the council of junior high school principals in Semarang.

\section{Data Collection Procedure and Tool}

The data in this study is the data of product relevancy to the students' need. The next data is the response of students and teachers in limited testing. The data collection procedure was carried out based on the stages of the research. In the identification and design stages, we collected the data of product relevancy through documentation and literature review. In the simulation and validation stages, we also collected data of product relevancy using questionnaire. The unsuitable product was used to improve the design of manipulatives and the tools. Further, in the limited testing stage, the students' and teachers' responses were obtained using questionnaire. The product relevancy data describe the quality of manipulatives as well as the response of the students and teachers. It can also be used to improve the design, tools, and production so that the quality of the manipulatives can be maintained.

\section{Data Analysis}

The data were analyzed both quantitatively and narratively. The quantitative data was the measurement result. Providing the production supporting tools and the improvement were analyzed using the quantitative and narrative method. The response of students and 
teachers were analyzed using descriptive percentage. The suitability of the students' and the teachers' response shows that both of them have the same interpretation of the use of manipulatives.

\section{RESULTS}

The identification towards individual manipulatives resulted in 14 types: kinds of triangle, kinds of quadrilateral, sum of angle magnitude in a triangle, area of rectangle, area of triangle, area of parallelogram, area of rhombus, area of trapezoid, circumference of circle, area of circle, the number of diagonals in a polygon, sum of angle magnitude in a polygon, Pythagorean theorem, Tangram-7 and its application.

\section{Individual Manipulative Design}

The design of individual manipulatives includes raw materials and sizes. The individual manipulatives were made with evafoam raw material with a thickness of 4 or $5 \mathrm{~mm}$ and a sufficient hardness. Some manipulatives with a thickness of $2 \mathrm{~mm}$ were also produced for more flexible products. Figure 3 is the example of the knife and the cutting result of the manipulatives.

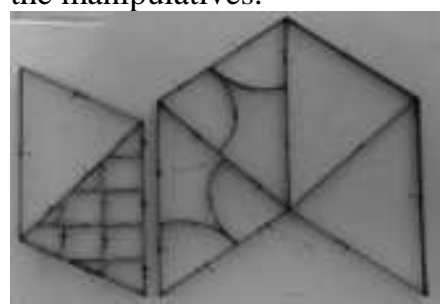

(a)

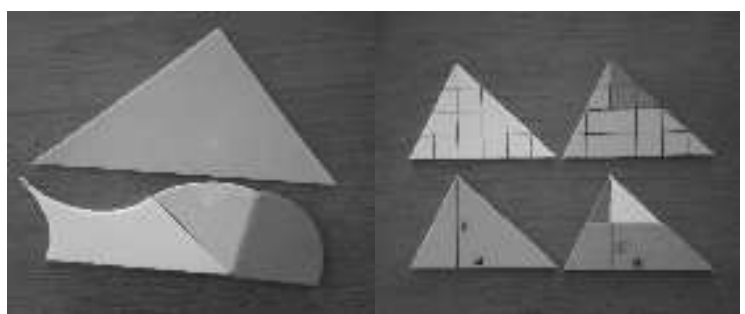

(b)

Figure 3

The knife (a) and the manipulatives as its cutting results (b)

Besides the knife, the main cutting tool in the individual manipulatives is the pressingcutting knife, as presented in Figure 4. The cutting process was done using a manual machine in the small industry.

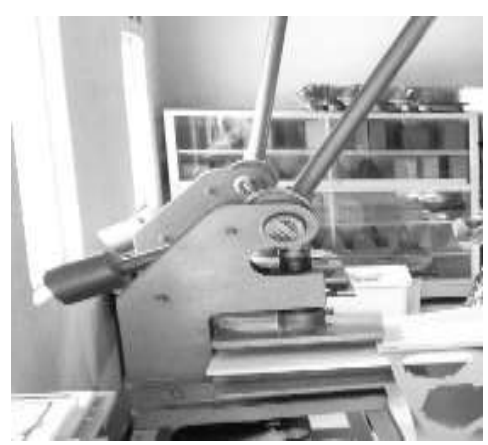

Figure 4

The pressing-cutting process of evafoam 
The cutting process needs to be done by an expert because it requires a great strength to pull or press the material and knife. Within 8 hours, it can produce around 300 sets of individual manipulatives. The results of the expert validation (academics) suggested that several parts of the cutting result must be revised because there is an inappropriate result. Moreover, the inappropriate results may occur due to inappropriate evafoam hardness. Thus, the material must be adjusted. Figure 5 presents the assembled Tangram-7 puzzle as the cutting results.

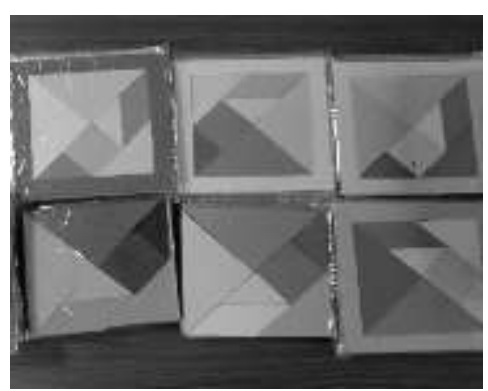

Figure 5

The examples of the assembled Tangram-7 puzzle

\section{Limited Testing Results}

The limited testing to the manipulative was conducted according to the material learned at school by 92 students of junior high school and 58 children in elementary school age at the Mathematics Village. We used Tangram-7 puzzle to the junior high school students in the setting of problem-based learning. Meanwhile, to the children of elementary school, we used Tangram 7 puzzle and planar figure manipulatives in the setting of discovery learning.

After the testing, we ask for the teachers and principals' response towards the use of manipulatives. The response is presented in Table 1.

Table 1

The students', teachers', and principals' responses towards the individual manipulatives

\begin{tabular}{lllll}
\hline \multirow{2}{*}{ No } & \multirow{2}{*}{ Aspects } & \multicolumn{3}{l}{ Percentage of positive response (Answering Yes) } \\
\cline { 3 - 5 } & & Students & Teacher & Principal \\
\hline 1 & Joyful & 95 & 100 & 100 \\
\hline 2 & $\begin{array}{l}\text { Flexible to try and to exercise } \\
\text { creative thinking }\end{array}$ & 91 & 100 & 100 \\
\hline 3 & Free to create & 94 & 100 & 98 \\
\hline 4 & Motivating to do the next steps & 83 & 98 & 100 \\
\hline 5 & Demand the students be confident & 82 & 100 & 98 \\
\hline 6 & Demand the students be discipline & 85 & 98 & 96 \\
\hline 7 & Demand the students think & 93 & 100 & 100 \\
\hline 8 & Creating activities are available & 80 & 98 & 100 \\
\hline
\end{tabular}




\section{Product Packaging and Marketing}

Product packaging was done practically using a plastic bag that has been equipped with the product name and product user manual. While marketing has been done by participating in the product exhibition. The products were displayed in the booth of Innovative Scientific Tools for Instruction (ISTI Corner), as presented in Figure 6.

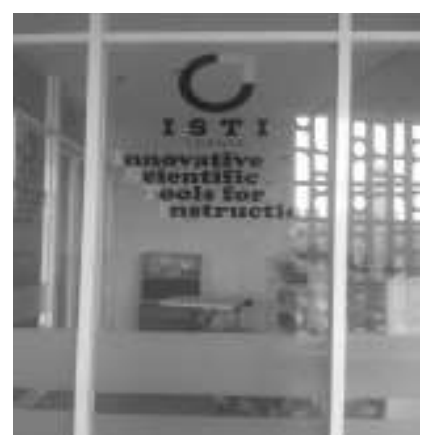

Figure 6

The display room for manipulatives product marketing

\section{DISCUSSION}

Based on the responses from the participants, there was not much revision for the manipulative's product design. The revised post-production product design was the design of cylinder and cone manipulatives. The revision is done on the location of the link so that it forms a better cylinder and cone model. The revised design was followed by the revision of the knife and the molding tools for cylinder and cone product. The post-production improvement was also applied to the determination of raw materials, namely the $2 \mathrm{~mm}$ evafoam should be adjusted by using the 320-gr ivory paper for the raw material. In the production stage, it was also necessary to use electrical power to run the pressing-cutting tool using the pneumatic system which was operated semiautomatically. The complementary component of the machine uses a $1000 \mathrm{~kg}$ pneumatic cylinder, assisted by a compressor. This engine range can put pressure on the knife and cut material by $1500 \mathrm{~kg}$ (1.5 tons). The design of the machine is presented in Figure 7.

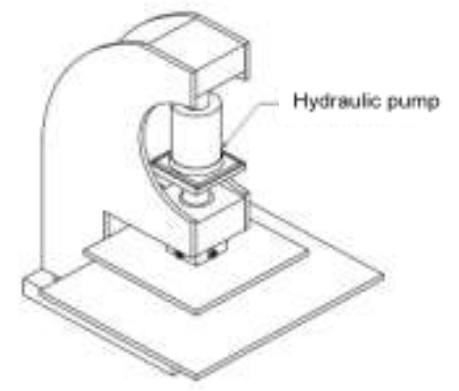

Figure 7

The pneumatic pressing-cutting machine 
The improved design, equipment, and production processes were carried out to improve the products to reach higher quality and can be used for the students' activities to exercise the higher-order thinking skills. Moreover, there was no obstacle in the production process, and it was low cost. The learning stages took the role as social and technical quality management. Therefore, the production process could produce highquality products.

\section{Manipulatives and the Activities}

One of the indicators of the effective use of manipulatives is the presence of instructions to guide the students' activities along with the use of the manipulatives (Cope, 2015). The use of individual manipulatives is targeted to facilitate the child to observe, to ask (think) to do the next activity, as a medium to produce information or data, to reason, as a means of communicating the work or ideas of students, and as a tool to create (MOEC, 2016). The example of manipulatives produced and used in mathematics learning is presented in Appendix 1. In Appendix 1, we present the design of the elementary school students' activities to transform a rectangle into various other shapes and determine the formula to find its area.

The students used the manipulative of the area of a rectangle (See Figure 8) and selfdevelop the formula of the rectangle area. Further, by cutting the model, the students could transform into various figures and determine the area.

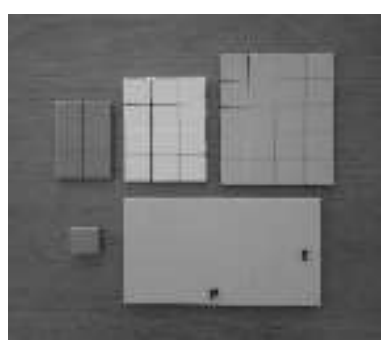

Figure 8

The manipulatives of rectangle area

The students are asked to observe and to think in various condition by counting the unit squares to determine the area of the presented rectangle. They are also asked to determine the area of Mr. Budi's yard presented in a word problem (See Appendix 1 Number 3). The students are demanded to determine the area of figures presented in a non-routine position. Some students could be misunderstood by thinking that the figure is parallelogram instead of a rectangle. The activities end by formulating the area of the rectangle. By following the series of activities, the students are facilitated to be used to dealing with critical and creative thinking. It is also in line with Laski's findings that a modified instruction with the use of manipulatives is effective to improve students' critical thinking and learning outcomes (Laski et al., 2015). The students' activities to construct the formula of the area of a rectangle using the manipulative indicates that the manipulative has facilitated the students to observe and to think following the series of activities in the manipulative manual. 
The other activities also developed for junior high school students for the manipulatives of Tangram-7. The result of the Tangram-7 production is presented in Figure 9.
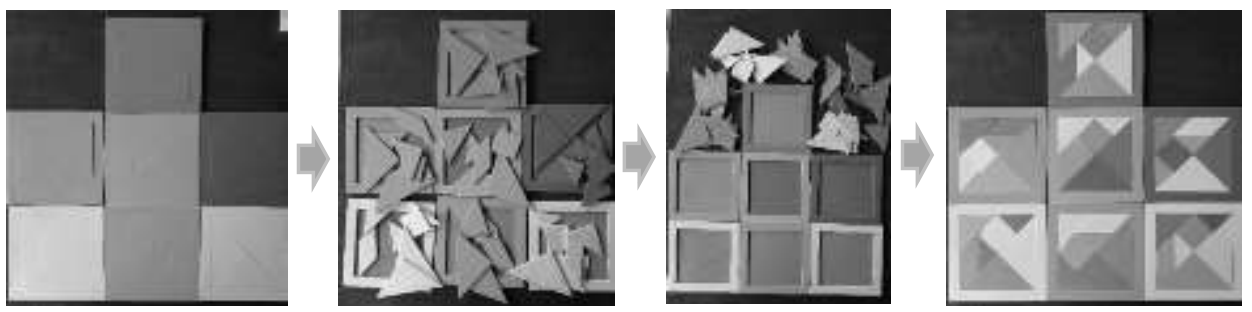

Figure 9

The production process of Tangram-7

To use the Tangram-7, we designed an activity of candle shape (See Figure 10). It is followed by a problem, "Given the length of the candle is $15 \mathrm{~cm}$, what is the surface area of the candle?" The problem becomes problematic not only for the students but also for the teachers. It was only $1.7 \%$ of the participants who could answer correctly. Surprisingly, after the students engaged in an activity using Tangram-7 manipulatives, they could solve the problem correctly though it was not $100 \%$.

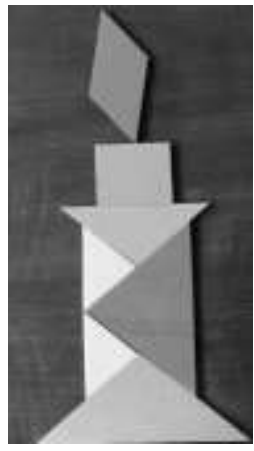

(a)

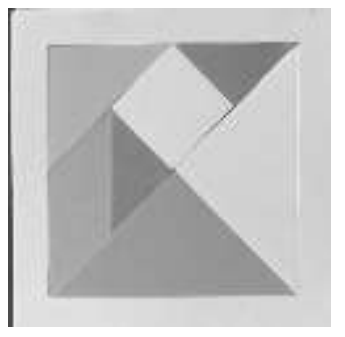

(b)

Figure 10

The candle shape (a) built from the Tangram-7 puzzle (b)

The shape of the candle as the problem stimulus and the activities in Tangram-7 could help to solve the problems. This is in line with the previous study that the teachers need to provide non-routine problems and actively involve the students in the learning process (student-centered learning) to facilitate the students to develop higher-order thinking skills (Agustyaningrum, 2015). Moreover, the other study found that the higher-order thinking skills can be developed through: (1) involving students in nonroutine problem solving activities; (2) facilitate the students to develop the ability to analyze, to evaluate (critical thinking), and to create so that the students have critical thinking and creativity; and (3) encouraging students to build their knowledge, so that learning becomes meaningful for them (Apino \& Retnawati, 2016). These abilities can 
be used to solve problems in everyday life. Some efforts must be made to improve creative thinking. Through the use of individual manipulatives, the results of this research product, accompanied by its activities, are expected to become habitual activities (physical and mental) which are the prerequisites and supporting factor for the development of the higher-order thinking skills of the elementary and junior high school students.

\section{CONCLUSION}

Many studies have confirmed the effectiveness of manipulatives to foster the students' higher order thinking skills, but the availability of manipulatives was still in a form of classical manipulatives. Therefore, individual manipulatives need to be developed to enable the students learn at anytime and anywhere outside school. To fulfill this demand, a product quality management needs to run in the form of research and development. The development has been done through eight stages of identification, design, preparation, production, simulation and validation, limited testing, packaging, and marketing. The process has successfully produced 14 individual manipulatives, referring to an appropriate design in terms of measurement, power and material efficiency, and setting practicality. The developed individual manipulatives are easy to use for children, joyful, demanding the students to think, providing the opportunity to be creative, full of spirit, demanding the students to be disciplined and confident. In the implementation of manipulatives, teachers and students gave positive responses - an average score of $94 \%$ - that the individual manipulatives support the development of the students' higher order thinking skills.

\section{REFERENCES}

Abdullah, A. H., Mokhtar, M., Halim, N. D. A., Ali, D. F., Tahir, L. M., \& Kohar, U. H. A. (2017). Mathematics Teachers' Level of Knowledge and Practice on the Implementation of Higher-Order Thinking Skills (HOTS). Eurasia Journal of Mathematics, Science \& Technology Education, 13(1), 3-17.

Agustyaningrum, N. (2015). Mengembangkan Keterampilan Berpikir Tingkat Tinggi dalam Pembelajaran Matematika SMP. Pythagoras: Journal Program Studi Pendidikan Matematika, 4(1), 39-46.

Armstrong, P. (2016). Bloom's taxonomy. Nasville: Vanderbilt University Center for Teaching.

Anderson, L., \& Krathwohl, D. R. (2001). A Taxonomy for Learning, Teaching, and Assessing: A Revision of Bloom's Taxonomy of Educational Objectives. Boston: Allyn \& Bacon.

Apino, E., \& Retnawati, H. (2016). Developing Instructional Design to Improve Mathematical Higher Order Thinking Skills of Students. Journal of Physics: Conference Series, 812(1), 012100.

Barros, S. A., Sampaio, P., \& Saraiva, P. (2014). Quality management principles and practices impact on the companies' quality performance. In 1st International Conference 
on Quality Engineering and Management (ICQEM 2014) (pp. 237-247). Guimaraes: University of Minho.

Cope, L. (2015). Math Manipulatives: Make the Abstract Tangible. Delta Journal of Education, 5(1), 10-19.

Dahlgaard-Park, S. M. (2011). The Quality Movement: Where Are You Going?. Total Quality Management \& Business Excellence, 22(5), 493-516.

Furner, J. M., \& Worrell, N. L. (2017). The importance of using manipulatives in teaching math today. Transformations, 3(1), 1-25.

Gall, M. D., Gall, J. P., \& Borg, W. R. (2003). Educational Research, An Introduction. Boston: Allyn and Bacon.

Harvey, B. (2005). Learning objects and instructional design. The International Review of Research in Open and Distributed Learning, 6(2), 1-7.

Hidayah, I., \& Sugiarto. (2015). Model of Independent Working Group of Teacher and its Effectiveness towards the Elementary School Teacher's Ability in Conducting Mathematics Learning. Procedia-Social and Behavioral Sciences, 214, 43-50.

Hidayah, I., Sugiarto, \& Dwijanto. (2016). The Role of Manipulatives Usage in Mathematics Learning of Primary Education with Scientific Approach towards the Students' Thinking Ability. International Journal of Applied Business and Economic Research, 14(10), 7215-7228.

Hidayah, I., Dwijanto, \& Istiandaru, A. (2018). Manipulatives and Question Series for Elementary School Mathematics Teaching on Solid Geometry. International Journal of Instruction, 11(3), 649-662.

Huang, C. Y., Kao, Y. S., Lu, H. H., \& Wu, M. J. (2017). Curriculum Development for Enhancing the Imagination in the Technology Commercialization Process. Eurasia Journal of Mathematics, Science and Technology Education, 13(9), 6249-6283.

Istiandaru, A., Istihapsari, V., Prahmana, R. C. I., Setyawan, F., \& Hendroanto, A. (2017). Characteristics of manipulative in mathematics laboratory. Journal of Physics: Conference Series, 943(1), 012023.

Juran, J. M., \& Godfrey, A. B. (1998). Juran's Quality Handbook 5th ed. New York: McGraw-Hill Professional.

Khoerunnisa, E., Hidayah, I., \& Wijayanti, K. (2016). Keefektifan pembelajaran think talk write berbantuan alat peraga mandiri terhadap komunikasi matematis dan percaya diri siswa kelas-VII. Unnes Journal of Mathematics Education, 5(1), 47-53.

Kontaş, H. (2016). The Effect of Manipulatives on Mathematics Achievement and Attitudes of Secondary School Students. Journal of Education and Learning, 5(3), 1020 . 
Krathwohl, D. R. (2002). A revision of Bloom's taxonomy: An overview. Theory into Practice, 41(4), 212-218.

Kull, T. J., \& Wacker, J. G. (2010). Quality management effectiveness in Asia: The influence of culture. Journal of Operations Management, 28(3), 223-239.

Laski, E. V., Jor'dan, J. R., Daoust, C., \& Murray, A. K. (2015). What makes mathematics manipulatives effective? Lesson from cognitive science and Montessori education. SAGE Open, 1-8.

Lee, C. Y., \& Chen, M. J. (2015). Effects of Polya Questioning Instruction for Geometry Reasoning in Junior High School. Eurasia Journal of Mathematics, Science \& Technology Education, 11(6), 1547-1561.

Limbach, B., \& Waugh, W. (2010). Developing Higher Level Thinking. Journal of Instructional Pedagogies, 3, 1-9.

Liu, X. (2010). Essentials of sciences classroom assessment. Thousand Oak: SAGE Publication.

Marshall, J. C., \& Horton, R. M. (2011). The relationship of teacher-facilitated, inquiry-based instruction to student higher-order thinking. School Science and Mathematics, 111(3), 93-101.

MOEC. (2016). Regulation of the Indonesian Ministry of Education and Culture number 22/2016 about the Standard of Process of Secondary Education. Jakarta: Ministry of Education and Culture.

Musfiqi, S., \& Jailani, J. (2014). Pengembangan Bahan Ajar Matematika yang Berorientasi pada Karakter dan Higher Order Thinking Skill (HOTS). PYTHAGORAS: Jurnal Pendidikan Matematika, 9(1), 45-59.

Newby, T. J., Stepich, D. A., Lehman, J. D., \& Russell, J. D. (2000). Instructional technology for teaching and learning: Designing instruction, integrating computers, and using media. Upper Saddle River: Merrill/Prentice Hall.

Ojose, B. (2008). Applying Piaget's theory of cognitive development to mathematics instruction. The Mathematics Educator, 18(1), 26-30.

Osman, R., Ong, E. T., Desa, S., \& Wong, K. T. (2012). Tahap Kemahiran Berfikir dalam Kalangan Guru Sekolah Rendah. Jurnal Pendidikan Bitara, 5, 1-11.

Saido, G. A., Siraj, S., Nordin, A. B., \& Al-Amedy, O. S. (2017). Teaching strategies for promoting higher order thinking skills: A case of secondary science teachers. MOJEM: Malaysian Online Journal of Educational Management, 3(4), 16-30.

Schniederjans, D., \& Schniederjans, M. (2015). Quality management and innovation: new insights on a structural contingency framework. International Journal of Quality Innovation, 1(1), 2-20. 
Toscano, R., Gavilán-Izquierdo, J. M., \& Sánchez, V. (2019). A Study of Pre-service Primary Teachers' Discourse when Solving Didactic-Mathematical Tasks. EURASIA Journal of Mathematics, Science and Technology Education, 15(11), 2-16.

van der Wiele, T., van Iwaarden, J., Williams, R., \& Eldridge, S. (2011). A new foundation for quality management in the business environment of the twenty-first century. Total Quality Management \& Business Excellence, 22(5), 587-598.

Zhang, Q., Feng, X., \& Xiang, X. (2016). The Impact of Quality Management Practices on Innovation in China: The Moderating Effects of Market Turbulence. American Journal of Industrial and Business Management, 6(3), 291-304.

\section{APPENDIX 1}

Example of activities to learn the area of a rectangle using manipulatives for elementary school.

\section{Manipulatives of Rectangle Area}

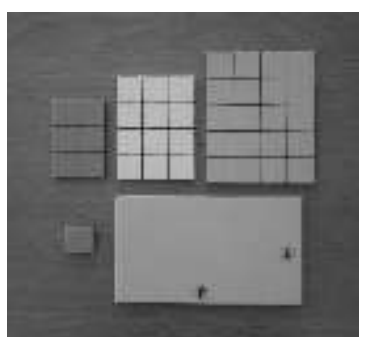

Figure 11

Rectangle area manipulatives

Take and put manipulatives on your table, as shown in Figure 11.

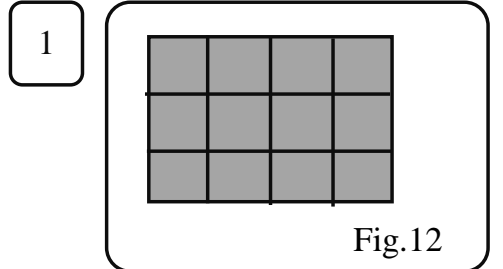

Observe the manipulative, as shown in Figure 12. The manipulative has a rectangle shape. The area of the rectangle is shown by the number of squares covering the entire region of the rectangle. 
Look at Figure 13.

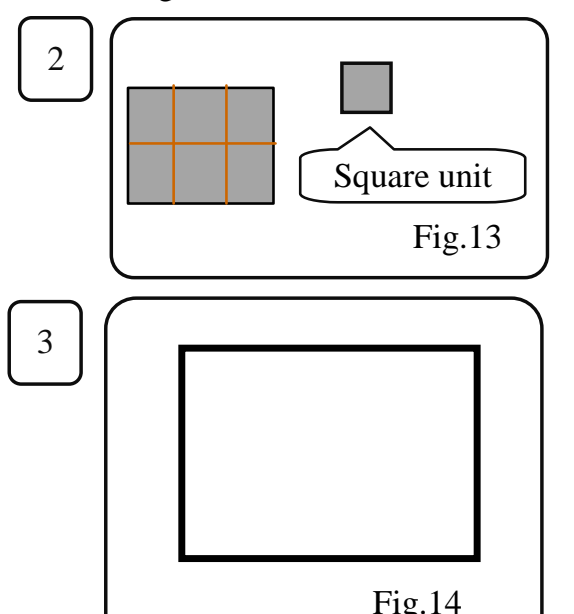

Fig.14
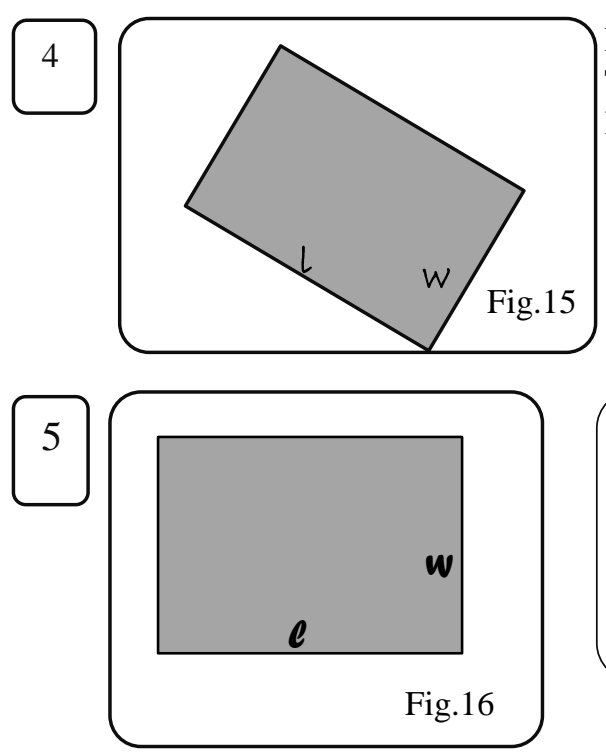

\begin{tabular}{|l|l|}
\hline Questions & Answer \\
\hline $\begin{array}{l}\text { a. How many squares covering } \\
\text { the entire region of the } \\
\text { rectangle in Figure 13? }\end{array}$ & \\
\hline b. What is the rectangle's area? & \\
\hline
\end{tabular}

Mr. Budi's yard has a rectangle shape, as illustrated in Figure 14. The size is 5 meters in length and 4 meters in width.

a. Make squares unit covering the entire area of the rectangle.

b. How many squares covering the entire region of the rectangle? What is the rectangle's area?

Put the manipulative, as shown in Figure 15.

The rectangle in Figure 1.5 has size 1 unit length and $\mathrm{w}$ units width.

\begin{tabular}{|l|l|}
\hline Question & Answer \\
\hline What is the rectangle's area? & \\
\hline
\end{tabular}

If a rectangle has length size of $\boldsymbol{C}$ unit and width size of $\boldsymbol{w}$ unit, then the area of the rectangle is

$$
A=\ldots
$$


Let's use the formula!
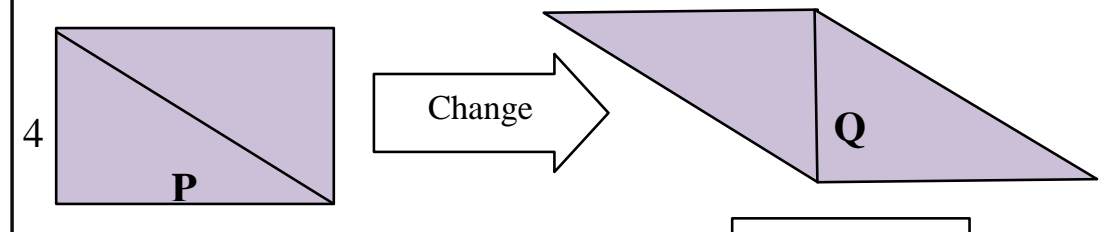

6

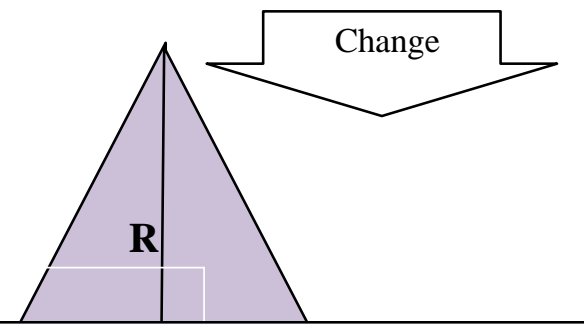

Look at Figure 17!

1. The shape of $\mathrm{P}$ is

Length $=$

Width $=$ Area of $\mathrm{P}=$

2. The shape of $Q$ is

Area of $Q=$

3. The shape of $\mathrm{R}$ is 